\title{
Evaluasi Aspek Green Building Pada Gedung Andi Hakim Nasoetion Rektorat IPB
}

\author{
Evaluation of Green Buliding Aspects in Andi Hakim Nasoetion IPB \\ Rectorate Building
}

\author{
Erizal $^{1, \mathrm{a})}$, Yudi Chadirin ${ }^{1, b)}$ \& Iriani Mustika Furi ${ }^{2, \mathrm{c})}$ \\ ${ }^{1)}$ Departemen Teknik Sipil dan Lingkungan, FATEKA, IPB, Bogor. \\ ${ }^{2)}$ Pasca Sarjana, Departemen Teknik Sipil dan Lingkungan, FATEKA, IPB, Bogor. \\ Koresponden : a)erizal@apps.ipb.ac.id, b)yudi@apps.ipb.ac.id \& \\ c)irianimustikafuri@yahoo.com
}

\begin{abstract}
ABSTRAK
Saat awal pembangunan Gedung AHN Rektorat IPB pada tahun 1995, lembaga untuk menyelenggarakan kegiatan sertifikasi atau penilaian bangunan hijau belum ada. Green Building Council Indonesia baru didirikan tahun 2009. Hal tersebut menjadi dasar dalam penelitian ini untuk mengevaluasi gedung AHN berdasarkan GREENSHIP yang merupakan program dari GBCI untuk kegiatan sertifikasi bangunan hijau. Tujuan dari penelitian ini adalah untuk mengevaluasi penerapan green building di gedung AHN dengan melakukan assessment atau penilaian aspek green building berdasaarkan GREENSHIP GBCI untuk gedung terbangun versi 1.0, kemudian memberikan suatu rekomendasi perbaikan pada aspek green building yang belum tercapai dan terpenuhi, tanpa merubah struktural dan arsitektural gedung. Metode penelitian yang digunakan adalah metode assesment dengan melakukan pengukuran penilaian berdasarkan kriteria green building yang mengacu pada standar nasional GREENSHIP GBCI dengan sistem rating untuk gedung terbangun ver. 1.0. Hasil assessment terhadap enam aspek pada kriteria green building berdasarkan GREENSHIP GBCI untuk gedung terbangun ver. 1.0, gedung AHN berhasil mendapatkan total 55 poin nilai atau $47 \%$ dari maksimal 117 poin nilai. Sesuai dengan peringkat GREENSHIP GBCI, gedung AHN Rektorat IPB mendapatkan peringkat Perak.
\end{abstract}

Kata Kunci : manajemen asset infrastruktur, infrastruktur, bangunan kantor, green building, evaluasi

\section{PENDAHULUAN}

Kesadaran manusia tentang lingkungan hidup dan permasalahan yang timbul akibat perubahan iklim kini semakin meningkat. Hal ini tidak terlepas dari apa yang kini sedang terjadi dengan bumi yaitu perubahan iklim dan isu pemanasan global (global warming). Berbagai kegiatan mengenai menjaga lingkungan hidup saat ini banyak di lakukan dengan berbagai cara dan inovasi untuk melindungi bumi. Upaya antisipasi pemanasan globalpun dilakukan oleh sektor bangunan. Pembangunan akan selalu membawa perubahan baik positif maupun negatif. Adanya perubahan lahan menjadi bangunan terbangun saja sudah dapat menghilangkan vegetasi pada lahan tersebut, vegetasi memiliki peran penting dalam mengatasi polutan maupun polusi udara yang terjadi. Vegetasi merupakan penghasil oksigen dan mengurangi karbondioksida, hal tersebut memiliki dampak terhadap perubahan kualitas udara. Menurut GBCI (2013) bangunan merupakan penyumbang gas rumah kaca terbesar di bumi. Sekitar 30-40\% emisi $\mathrm{CO}_{2}$ dihasilkan oleh bangunan. Bangunan mempunyai andil yang 
cukup signifikan dalam proses kerusakan lingkungan, oleh karenanya, hal yang paling potensial untuk mengantisipasi kerusakan bumi lebih efektif melalui bangunan, salah satunya dengan mengimplementasikan konsep bangunan ramah lingkungan atau biasa disebut dengan konsep green building (Firsani \& Utomo 2012).

Bagi manajemen aset infrastruktur dan fasilitas, mempunyai kualitas green atau sustainibility yang baik merupakan salah satu tujuan utama manajemen aset infrastruktur dan fasilitas (Soemitro \& Suprayitno 2018; Suprayitno \& Soemitro 2018). Oleh karena itu mengevaluasi kualitas aspek green dari bangunan gedung merupakan suatu hal yang sangat penting.

Indonesia kini memiliki lembaga untuk menyelenggarakan kegiatan sertifikasi atau penilaian bangunan hijau yaitu Green Building Council Indonesia atau Lembaga Konsil Bangunan Hijau Indonesia. Salah satu program GBCI adalah menyelenggarakan kegiatan sertifikasi bangunan hijau di Indonesia berdasarkan peringkat penilaian khas Indonesia yang disebut GREENSHIP. Konsep green building dapat diterapkan untuk gedung baru dan gedung terbangun. Saat awal pembangunan Gedung AHN Rektorat IPB pada tahun 1995, lembaga untuk menyelenggarakan kegiatan sertifikasi atau penilaian bangunan hijau belum ada, GBCI didirikan pada tahun 2009. Hal tersebut menjadi dasar penelitian ini untuk mengevaluasi gedung AHN Rektorat IPB berdasarkan GREENSHIP.

Penelitian ini dilakukan untuk mengevaluasi dan menilai apakah gedung Andi Hakim Nasoetion (AHN) Rektorat IPB memenuhi standar green building dan sampai sejauh mana penerapan aspek green building yang ada di gedung AHN Rektorat IPB berdasarkan acuan dari GREENSHIP GBC Indonesia dengan sistem rating untuk bangunan terbangun versi 1.0. Penelitian ini dapat memberikan suatu rekomendasi untuk menambahkan aspek green building yang belum terpenuhi di gedung AHN Rektorat IPB. Dengan menerapkan konsep green building diharapkan gedung rektorat IPB akan lebih hemat energi, meminimalkan dampak kerusakan lingkungan, dan dapat dijadikan perbandingan untuk mengkaji gedunggedung lain di kampus IPB.

\section{METODE}

\section{Waktu dan Lokasi Penelitian}

Penelitian dilaksanakan mulai bulan Februari 2015 - Mei 2015. Lokasi penelitian dilakukan di gedung Andi Hakim Nasoetion Rektorat IPB di Jalan Lingkar Akademik, Kampus IPB Dramaga, Bogor.

\section{Alat dan Bahan}

Alat dan bahan yang digunakan dalam penelitian ini meliputi: perangkat analisis green building GBCI greenshiprating tools untuk gedung terbangun versi 1.0, perangkat pengukurannya antara lain GPS (Global Positioning System), anemometer (MastechMS6252A), gas sampler impinger (Binalab-CS596AC), lux meter (Krisbow-KW06291), sound level meter (Krisbow-KW06291), photometer (Pallintest-8000), pH meter (pHepHanna), eco tester TDS high (Oakton), microprocessor turbidity meter (Hanna Instrument93703), komputer laptop Windows 7, software microsoft office 2010, autocad 2010 dan arcGIS 10.

\section{Prosedur Analisis Data}

Penelitian ini dilakukan dengan metode Assesment atau penilaian dengan melakukan pengukuran penilaian terhadap kriteria green building yang mengacu pada standar nasional Greenship GBCI dengan sistem rating untuk gedung terbangun ver. 1.0. Pengumpulan data dalam penelitian ini berasal dari data primer dan data sekunder. Data primer diperoleh melalui pengukuran langsung dilapangan, survei, wawancara dan kuisioner. Sedangkan data sekunder 
peneliti peroleh dari pihak lain, dimana data tersebut telah didokumentasikan dalam bentuk catatan, laporan, arsip dan data pendukung lainnya. Berikut adalah analisa penilaian dari masing-masing kriteria pada 6 parameter yang telah ditetapkan GBCI, yaitu:

\section{Tepat Guna Lahan (Appropriate Site Development-ASD)}

Untuk mengetahui berapa nilai poin yang diperoleh pada parameter ASD dilakukan pengukuran, wawancara dan survei. Wawancara kepada pihak manajemen puncak untuk mengetahui adanya surat pernyataan yang memuat komitmen mengenai pemeliharaan eksterior bangunan dan pengurangan pemakaian kendaraan bermotor pribadi. Selain wawancara dilakukan pengukuran dan survei antara lain:

- Pengukuran untuk mengetahui terdapat minimal 5 jenis fasilitas umum dalam jarak pencapaian jalan utama sejauh $1.500 \mathrm{~m}$ dari tapak.

- Survei fasilitas pejalan kaki yang aman, nyaman dan bebas dari perpotongan akses kendaraan bermotor untuk menghubungkan minimal 3 fasilitas umum.

- Survei penyediaan shuttle bus bagi pengguna gedung untuk mencapai stasiun transportasi umum dan pengurangan pemakaian kendaraan pribadi bermotor.

- Adanya vegetasi (softscape) yang bebas dari bangunan taman (hardscape) yang terletak di atas permukaan tanah seluas minimal 30\% luas total lahan. Formasi tanaman sesuai dengan Permen PU No. 5/PRT/M/2008 mengenai Ruang Terbuka Hijau (RTH) Pasal 2.3.1 tentang Kriteria Vegetasi untuk Pekarangan.

- Penggunaan bahan dengan nilai albedo rata-rata minimal 0,3.

- Pengurangan beban volume limpasan air hujan sebesar 50\% berdasarkan perhitungan debit air hujan pada bulan basah. Menurut Asdak (2007) untuk memprakirakan besarnya air larian (limpasan), metode rasional adalah salah satu teknik yang dianggap memadai. Dengan rumus sebagai berikut:

$$
\begin{aligned}
& \mathrm{Q}=0,0028 \text { C.i.A } \\
& \text { Keterangan: } \\
& \begin{aligned}
& \mathrm{Q}= \text { air larian (debit) puncak }\left(\mathrm{m}^{3} / \mathrm{dt}\right) \\
& \mathrm{C}=\text { koefisien air larian } \\
& i \quad=\text { intensitas hujan }(\mathrm{mm} / \mathrm{jam}) \\
& \mathrm{A} \quad=\text { luas daerah tangkapan air hujan }
\end{aligned}
\end{aligned}
$$

Data sekunder dalam kategori ini adalah data curah hujan dari stasiun klimatologi Darmaga Bogor.

- Survei adanya pendekatan lingkungan dan membuka akses pejalan kaki ke dua orientasi bangunan tetangga.

\section{Efiiensi dan Konservasi Energi (Energy Efficiency and Conservation-EEC)}

Untuk mengetahui berapa nilai poin yang diperoleh pada parameter EEC dilakukan wawancara kepada manajemen puncak untuk mengetahui adanya kampanye dalam rangka mendorong penghematan energi dengan minimal pemasangan kampanye tertulis secara permanen di setiap lantai. Selain wawancara dilakukan pengukuran dan survei, antara lain:

- Pengukuran dan survei nilai poin pada aspek efisiensi kebutuhan energi dengan menunjukkan IKE (Intensitas Konsumsi Energi) listrik dengan nilai dibawah IKE listrik standar acuan dalam 6 bulan terakhir.

- Adanya pencatatan rutin bulanan hasil pantau dan koleksi data pada kWh meter minimal selama 6 bulan terakhir.

- Adanya penerapan dukungan teknologi untuk memonitoring dan mengontrol peralatan gedung melalui teknologi EMS (Energy Monitoring System). 


\section{Konservasi Air (Water Conservation-WAC)}

Untuk mengetahui berapa nilai poin yang diperoleh pada parameter WAC dilakukan survei dan pengukuran sebagai berikut:

- Survei adanya kampanye konservasi air, minimal kampanye tertulis berupa stiker, poster dan email.

- Survei adanya sub-meter konsumsi air pada sistem area publik, SOP mengenai pemeliharaan dan pemeriksaan sistem plambing secara berkala.

- Perhitungan untuk mengetahui adanya penurunan jumlah konsumsi air sesuai acuan SNI 03-7065-2005 tentang Tata Cara Pelaksanaan Sistem Plambing.

- Survei mengenai bukti laboratorium 6 bulan terakhir dari sumber air primer yang sesuai dengan kriteria air bersih dan pengujian kualitas air bersih gedung AHN Rektorat IPB.

- Survei mengenai air daur ulang, sistem filtrasi yang menghasilkan air minum yang sesuai dengan Permenkes No. 492 tahun 2010 tentang Persyaratan Kualitas Air Minum.

\section{Sumber dan Siklus Material (Material Resources and Cycle-MRC)}

Untuk mengetahui berapa nilai poin yang diperoleh pada parameter MRC dilakukan wawancara dan survei sebagai berikut:

- Survei mengenai penggunaan refrigerant non-CFC dan bahan pembersih yang memiliki nilai Ozone Depleting Potential (ODP) kecil, $<1$

- Survei daftar material yang ramah lingkungan dan adanya dokumen yang menjelaskan pembelajaan material tersebut.

- Survei adanya SPO laporan untuk mengumpulkan dan memilah sampah berdasarkan jenis organik dan non organik dan upaya penanganan sampah dari kegiatan renovasi ke pihak ketiga dan SPO penyaluran barang bekas yang masih dapat dimanfaatkan kembali.

\section{Kesehatan dan Kenyamanan dalam Ruang (Indoor Health and Comfort-IHC)}

Untuk mengetahui berapa nilai poin yang diperoleh pada parameter IHC dilakukan wawancara kepada pihak manajemen puncak, untuk mengetahui adanya surat yang memuat komitmen untuk mendorong minimalisasi aktifitas merokok dalam gedung. Selain wawancara, dilakukan survei dan pengukuran antara lain:

- Survei adanya kampanye dilarang merokok dan dilarang merokok dieluruh area gedung, pembersihan filter, coil pendingin dan alat bantu VAC (Ventilation and Air Conditioning) dan survei kenyamanan pengguna gedung.

- Pengukuran mengenai kualitas udara ruangan yang menunjukkan adanya introduksi udara luar minimal sesuai dengan SNI-03-6572-2001 tentang Tata Cara Ventilasi dan Sistem Pengkondisian Udara pada Bangunan Gedung. Rumus untuk menghitung laju udara ventilasi berdasarkan perbedaan tekanan angin menurut Satwiko (2009) adalah sebagai berikut:

$\mathrm{Q}=\mathrm{Cv} \cdot \mathrm{A} . \mathrm{V}$

Keterangan:

$\mathrm{Q}=$ Laju ventilasi $\left(\mathrm{m}^{3} /\right.$ detik $)$

$\mathrm{A}=$ Luas bukaan inlet $\left(\mathrm{m}^{2}\right)$

$\mathrm{V}=$ Kecepatan angin $(\mathrm{m} /$ detik)

$\mathrm{Cv}=$ Efektivitas bukaan (0,5-0,6 apabila arah datang angin tegak lurus bukaan dan 0,25-0.35 untuk arah angin diagonal) untuk luas area bukaan inlet dan outlet yang sama.

- Pengukuran tingkat pencahayaan (iluminasi) sesuai dengan SNI 03-6197-2000 tentang Konservasi Energi pada Sistem Pencahayaan. 
- Pengukuran tingkat bunyi di ruang kerja sesuai dengan SNI 03-6386-2000 tentang Spesifikasi Tingkat Bunyi dan Waktu Dengung dalam Bangunan Gedung dan Perumahan. Rumus perhitungan tingkat kebisingan adalah sebagai berikut:

$$
\begin{aligned}
& \operatorname{Leq}(1 \text { menit })=10 \log \frac{1}{60}\left(10^{0,1 L 1}+10^{0,1 L 2}+\ldots+10^{0,1 L 12}\right) \cdot 5 d b(A) \\
& \begin{aligned}
\text { Leq }(10 \text { menit }) & =10 \log \frac{1}{10}\left(10^{0,1 L I}+10^{0,1 L I I}+\ldots+10^{0,1 L X}\right) \cdot 1 d b(A) \\
& =10 \log \frac{1}{11}\left(\operatorname{Ta} 10^{0,1 L a}+T b 10^{0,1 L b}+T c 10^{0,1 L c}\right) d b(A)
\end{aligned}
\end{aligned}
$$

Keterangan :

Leq $=$ Equivalent Continuous Noise Level, merupakan nilai tingkat kebisingan yang berfluktuatif selama waktu tertentu dan setara kebisingan yang ajeg pada selang waktu yang sama (dBA)

$\mathrm{L}_{1}, \ldots, \mathrm{L}_{10}=$ Tingkat kebisingan yang terbaca pada detik ke-n selama 1 menit (dBA)

$\mathrm{L}_{\mathrm{I}}, \ldots . ., \mathrm{L}_{\mathrm{X}}=$ Tingkat kebisingan yang terbaca pada detik ke-n selama 10 menit (dBA)

Ls $\quad=$ Leq selama siang hari $(\mathrm{dBA})$

$\mathrm{Ta}, \mathrm{Tb}, \mathrm{Tc}=$ Rentang waktu pengukuran $(\mathrm{Ta}=3, \mathrm{~Tb}=2$, dan $\mathrm{Tc}=6)(\mathrm{Jam})$

$\mathrm{La}=$ Leq (10 menit) pada rentang waktu pukul 06.00-09.00 (dBA)

$\mathrm{Lb}=$ Leq (10 menit) pada rentang waktu pukul 09.00-11.00 (dBA)

Lc $\quad=$ Leq (10 menit) pada rentang waktu pukul 11.00-17.00 (dBA)

\section{Manajemen Lingkungan Bangunan (Building Environment Management-BEM)}

Untuk mengetahui berapa nilai poin yang diperoleh pada parameter BEM dilakukan wawancara kepada pihak manajemen puncak mengenai adanya rencana operation \& maintenance yang dititik beratkan pada: sistem mekanikal dan elektrikal, sistem plambing dan kualitas air, pemeliharaan eksterior dan interior, dan pengelolaan sampah. Survei aplikasi inovasi dengan meningkatkan kualitas bangunan dan dengan melakukan pendekatan manajemen. Data sekunder yang diperoleh berupa dokumen As Built Drawing gedung.

\section{HASIL DAN PEMBAHASAN}

GBCI (2013) menjelaskan bahawa sistem rating GREENSHIP merupakan alat bantu bagi para pelaku industri bangunan, baik pengusaha, engineer, maupun pelaku lainnya dalam menerapkan best practices dan mencapai standar terukur yang dapat dipahami oleh masyarakat umum, terutama tenant dan pengguna bangunan.. Kriteria penilaiannya dikelompokkan menjadi enam kategori, yaitu :

1. Appropriate site development/ASD (tepat guna lahan)

2. Energy efficiency and conservation/EEC (efisiensi dan konservasi energi)

3. Water conservation/WAC (konservasi air)

4. Material resources and cycle/MRC (sumber dan siklus material)

5. Indoor air health and comfort/IHC (kualitas udara dan kenyamanan ruangan)

6. Building and environment management/BEM (manajemen lingkungan bangunan) berikut.

Peringkat pada GREENSHIP tahap final assessment terdiri dari empat peringkat sebagai

Platinum : Minimum persentase $73 \%$ dengan 86 poin

Gold : Minimum persentase $57 \%$ dengan 67 poin

Silver : Minimum persentase $46 \%$ dengan 54 poin

Bronze : Minimum persentase $35 \%$ dengan 41 poin 
Berikut adalah hasil assessment terhadap kriteria green building yang dilakukan pada gedung AHN Rektorat IPB berdasarkan tolak ukur GREENSHIP untuk gedung terbangun versi 1.0:

\section{Tepat Guna Lahan (Appropriate Site Development-ASD)}

Aspek ASD terdiri dari 2 rating prasyarat dan 8 rating biasa dengan total nilai maksimal adalah 16 poin. Hasil penilaian terhadap rating aspek ASD berdasarkan greenship adalah sebagai berikut :

a) Terdapat standar operasional prosedur (SOP) perawatan bangunan, perawatan bangunan yang dimaksud adalah perawatan fisik (konstruksi) terhadap bagian struktur dan arsitektur bangunan.

b) Terdapat minimal 5 jenis fasilitas umum dalam jarak pencapaian jalan utama sejauh $1.500 \mathrm{~m}$ dari tapak. Dari gedung AHN Rektorat terdapat 15 jenis fasilitas umum dalam pencapaian $1.500 \mathrm{~m}$ dari tapak, dengan data sebagai berikut.

Tabel 1. Jarak 15 Fasilitas Umum dari Gedung AHN Rektorat

\begin{tabular}{clc}
\hline No & Keterangan & Jarak $(\mathbf{m})$ \\
\hline 1 & Bank Mandiri & 41 \\
2 & Bank BNI & 725 \\
3 & Bank BRI & 768 \\
4 & ATM Center & 755 \\
5 & Perpustakaan & 1.013 \\
6 & Musholla & 145 \\
7 & Masjid Alhuriyah & 707 \\
8 & Kantin Zeamays & 119 \\
9 & Poliklinik & 785 \\
10 & Kantor Polisi & 697 \\
11 & Kantor Lurah & 800 \\
12 & Pedagang Kaki Lima (Bara) & 878 \\
13 & Gelanggang Olah Raga (GOR) & 774 \\
14 & Mini Market Agrimart & 902 \\
15 & Halte Bus Umum & 1.415 \\
Sumber: GBCI (2011) Greenship Rating Tools Version 1.0 untuk Gedung Terbangun, diolah.
\end{tabular}

c) Terdapat fasilitas pejalan kaki yang aman, nyaman dan bebas dari perpotongan akses kendaraan bermotor untuk menghubungkan 3 fasilitas umum yaitu Bank Mandiri, musholla dan kantin Zeamays.

d) Menyediakan shuttle bus bagi pengguna gedung untuk mencapai stasiun transportasi. IPB mempunyai bus karyawan yang dapat digunakan oleh pegawai gedung AHN Rektorat IPB.

e) Pengurangan pemakaian kendaraan pribadi bermotor. Gedung AHN Rektorat IPB telah mempunyai bus karyawan dan fasilitas umum bus IPB di dalam kampus untuk aksesibilitas di areal kampus IPB. Kemudian adanya fasilitas mobil listrik yang lebih ramah bagi lingkungan.

f) Hasil perhitungan luasan area tapak Gedung AHN Rektorat IPB :
Bangunan Terbangun $\quad=4567,07 \mathrm{~m}^{2}$
Ruang Hijau (Softcase) $=3554,96 \mathrm{~m}^{2}$
Lahan Terbuka $\quad=3557,70 \mathrm{~m}^{2}$
Total Lahan $\quad=11679,74 \mathrm{~m}^{2}$

Persentase softcase terhadap total luas lahan gedung AHN Rektorat IPB adalah 30,43\%, hal ini telah sesuai dengan tolak ukur pada site landscaping. 
g) Gedung AHN Rektorat IPB menggunakan material tutupan atap berupa ceramic roof tile (genting keramik yang terbuat dari tanah liat yang dilapis glazur). Nilai albedo dari genting tanah liat adalah sebesar 0,4 (Komalasari dkk., 2013). Untuk tolak ukur non atap yang tertutup perkerasan gedung AHN Rektorat IPB menggunakan beton dengan nilai albedo 0,55 (Rushayati dkk., 2010).

h) Peluang kejadian hujan bulan basah di hitung berdasarkan data curah hujan harian yang didapatkan dari stasiun klimatologi Darmaga Bogor dengan rentang 11 tahun dari tahun 2004-2014.

Tabel 2. Hasil perhitungan limpasan gedung AHN Rektorat IPB

\begin{tabular}{|c|c|c|c|c|}
\hline Penggunaan Lahan & Luas (ha) & $i(\mathbf{m m} / \mathbf{j a m})$ & $\mathbf{C}$ & $\mathbf{Q}\left(\mathrm{m}^{3} / \mathrm{s}\right)$ \\
\hline Bangunan & 0,46 & 0,18 & 0,65 & 0,000149 \\
\hline Ruang hijau & 0,36 & 0,18 & 0,15 & 0,000027 \\
\hline Lahan terbuka & 0,36 & 0,18 & 0,80 & 0,000143 \\
\hline Total & 1,17 & & 1,60 & 0,000319 \\
\hline
\end{tabular}

Pada Tabel 2 dapat dilihat bahwa beban volume limpasan di gedung AHN Rektorat IPB adalah $0,000319 \mathrm{~m}^{3} / \mathrm{s}$ atau $3,695602 \mathrm{~mm}^{3} /$ hari. Untuk volume hujan harian yang di hitung berdasarkan perhitungan debit air hujan pada bulan basah di gedung AHN Rektorat IPB adalah 10,81 $\mathrm{mm} /$ hari. Persentase beban volume limpasan air hujan terhadap beban volume hujan harian pada bulan basah adalah $34 \%$, sehingga air yang terserap ke tanah kurang lebih $66 \%$.

i) Dalam pendekatan terhadap lingkungan, disekitar gedung AHN Rektorat IPB terdapat tempat ibadah berupa musholla termasuk wc didalamnya yang dapat digunakan oleh masyarakat umum, kemudian mengalokasikan lahan khusus untuk kantin yaitu kantin Makjan, kaki lima berjarak kurang lebih $878 \mathrm{~m}$ dari tapak nama lokasinya adalah Babakan Raya.

j) Untuk gedung AHN Rektorat IPB orientasi menuju bangunan tetangga terdapat di sebelah selatan gedung yaitu gedung Pasca Sarjana IPB, dan disebelah timur adalah gedung Auditorium AHN IPB.

Hasil assessment terhadap aspek ASD yang dilakukan pada gedung AHN Rektorat IPB menunjukkan bahwa perolehan poin nilai yang didapat adalah 12 poin dari nilai maksimal 16 poin sehingga telah memenuhi $75 \%$ dari rating yang telah di tetapkan greenship GBCI.

\section{Efisiensi dan Konservasi Energi (Energy Efficiency and Conservation-EEC)}

Aspek EEC terdiri dari 2 rating prasyarat, 5 rating biasa dan 2 rating bonus dengan total nilai maksimal adalah 36 poin. Hasil penilaian terhadap rating aspek ASD berdasarkan greenship adalah sebagai berikut :

a) Gedung AHN Rektorat IPB telah melakukan kampanye berupa stiker hemat energi yang di tempel di hampir seluruh WC di setiap lantai.

b) Nilai IKE pada gedung rektorat adalah sebesar $91,42 \mathrm{kWh} / \mathrm{m}^{2}$.tahun dan lebih kecil dari IKE standar acuan yaitu $250 \mathrm{kWh} / \mathrm{m}^{2}$.tahun dengan demikian didapatkan penghematan sebesar $63 \%$ dari standar acuan yang ditetapkan. Pencatatan $\mathrm{kWh}$ meter dilakukan rutin setiap bulan.

c) Menerapkan dukungan teknologi untuk memonitoring dan mengontrol peralatan gedung melalui teknologi EMS (Energy Management System). Pada bulan Januari 2015 gedung AHN Rektorat IPB mulai mencoba penggunaan teknologi EMS yaitu IPB Innovative Monitoring System yang bekerjasama dengan perusahan Fujitsu. Teknologi ini dilengkapi dengan fungsi sebagai fasilitas pengumpulan informasi konsumsi energi dengan memperlihatkan data dan menganalisisnya. Data yang didapat berupa visualisasi 
konsumsi energi yang digunakan, analisis data, kontrol peralatan, dan membantu mengurangi biaya permintaan energi gedung (Ichimura dkk., 2014). Teknologi ini baru di uji cobakan di seluruh ruangan lantai 2 gedung AHN Rektorat IPB.

Hasil assessment terhadap aspek EEC yang dilakukan pada gedung AHN Rektorat IPB menunjukkan bahwa perolehan poin nilai yang didapat adalah 20 poin dari nilai maksimal 36 poin sehingga telah memenuhi 56\% dari rating yang telah di tetapkan greenship GBCI.

\section{Konservasi Air (Water Conservation-WAC)}

Aspek WAC terdiri dari 1 rating prasyarat, 7 rating biasa dan 1 rating bonus dengan total nilai maksimal adalah 20 poin. Hasil penilaian terhadap rating aspek WAC berdasarkan greenship adalah sebagai berikut :

a) Gedung AHN Rektorat IPB telah melakukan kampanye berupa stiker hemat air yang di tempel permanen di hampir seluruh WC di setiap lantai.

b) Sub meter gedung AHN Rekorat IPB tergabung di dalam sub meter induk yang terdiri dari 4 titik pelayanan. Empat titik pelayanan tersebut yaitu gedung AHN Rektorat IPB, gedung Pascasarjana IPB, gedung LPPM (Lembaga Penelitian dan Pengabdian Masyarakat) dan yang terakhir adalah Kantin.

c) Tolak ukur dalam Fresh Water Efficiency adalah untuk gedung dengan konsumsi air $20 \%$ diatas SNI, setiap penurunan $10 \%$ mendapat 1 poin sampai mencapai standar acuan (SNI 03-7065-2005 tentang Tata Cara Pelaksanaan Sistem Plambing). Menurut SNI (2005) standar/base line minimum konsumsi air yang ditetapkan untuk gedung perkantoran adalah 50 liter/hari/pekerja. Jika dikonversikan dengan waktu kerja bulanan rata-rata 22 hari, didapatkan base line sebesar 1100 liter/bulan/pekerja dan 1320 liter/bulan/pekerja untuk nilai 20\% diatas standar SNI. Untuk mengetahui pemakaian konsumsi air khusus untuk gedung AHN Rektorat IPB, dilakukan dengan metoda penaksiran laju air, salah satu metodanya dilihat berdasarkan jumlah pemakai, metode ini didasarkan pada pemakaian air rata-rata sehari dari setiap penghuni, dan perkiraan jumlah penghuni. Apabila jumlah penghuni diketahui untuk satu gedung, maka angka yang dipakai untuk menghitung pemakaian air rata-rata sehari-hari berdasarkan tabel "standar" mengenai pemakaian air per orang per hari. (Morimura 2000).

Hal ini dikarenakan tidak ada meteran khusus untuk mengetahui jumlah konsumsi air yang digunakan pada gedung AHN Rektorat IPB saja. Data konsumsi air yang ada berupa jumlah konsumsi air gabungan dari submeter induk yang melayani 4 titik pelayanan termasuk gedung AHN Rektorat IPB. Jika di asumsikan seluruh titik pelayanan mengkonsumsi $20 \%$ diatas standar SNI yang ditetapkan, maka berdasarkan jumlah populasi disetiap titik pelayanan tersebut prediksi jumlah konsumsi air pada setiap titik pelayanan akan dapat diketahui. Berikut adalah hasil perhitungan prediksi jumlah konsumsi air di setiap titik pelayanan.

Tabel 3. Prediksi Jumlah Konsumsi Air di Setiap Titik Pelayanan

\begin{tabular}{ccccc}
\hline Titik Pelayanan & $\begin{array}{c}\text { Standar } \\
\text { Kebutuhan Air } \\
\text { (l/bulan/orang) }\end{array}$ & $\begin{array}{c}\text { Populasi } \\
\text { Penghuni Tetap } \\
\text { (orang) }\end{array}$ & $\begin{array}{c}\text { Jumlah } \\
\text { Konsumsi Air } \\
\text { (l/bulan) }\end{array}$ & $\begin{array}{c}\text { Total Konsumsi } \\
\text { Air } \\
\text { (l/bulan) }\end{array}$ \\
\hline AHN Rektorat IPB & 1.320 & 637 & 840.840 & \\
LPPM & 1.320 & 23 & 30.360 & 983.400 \\
Pascasarjana & 1.320 & 55 & 72.600 & \\
Kantin & 396 & 100 & 39.600 &
\end{tabular}




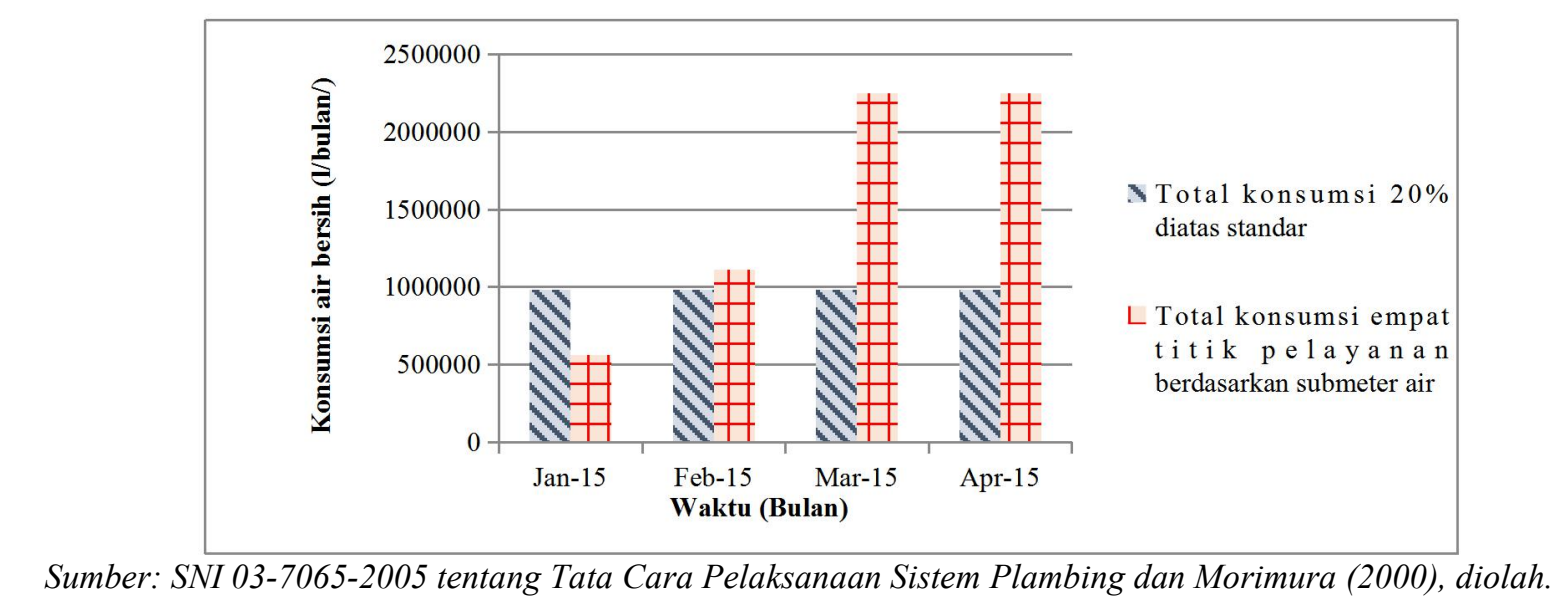

Gambar 1. Perbandingan Prediksi Konsumsi Air Bersih

Pada Gambar 1, terlihat jumlah prediksi konsumsi air di bulan Januari untuk total konsumsi air pada empat titik pelayanan berdasarkan data dari submeter induk adalah sebesar $565000 l$ dan mempunyai nilai lebih kecil dari prediksi jumlah total konsumsi $20 \%$ di atas standar SNI dengan empat titik pelayanan yaitu 983.400 ( $l /$ bulan), Dengan tingginya jumlah konsumsi air pada empat titik pelayanan berdasarkan data dari submeter induk di bulan Februari-April menunjukkan tidak adanya upaya penghematan pada setiap titik pelayanan.

d) Tolak ukur dalam Fresh Water Efficiency adalah Pasokan air gedung AHN Rektorat IPB berasal dari WTP Cihideung. WTP Cihideung merupakan instalasi pengolahan air bersih yang dimiliki oleh IPB, sumber air pengolahannya adalah dari air sungai. Air dari WTP Cihideung digunakan untuk kebutuhan air di gedung AHN Rektorat IPB termasuk untuk kebutuhan penggunaan flushing WC di gedung AHN Rektorat IPB. WTP Cihideung menggunakan tolak ukur sesuai Permenkes, proses monitoring kualitas air hasil olahan pada setiap proses pengolahan di WTP Cihideung dilakukan setiap hari minimal sekali sehari dan dibuat dalam laporan bulanan.

e) Adanya penghematan penggunaan air tanah. Gedung Rektorat AHN IPB tidak menggunakan air tanah sebagai pasokan air untuk gedung karena pasokan air berasal dari WTP Cihideung yang merupakan instalasi pengolahan air bersih yang dimiliki oleh IPB.

Hasil assessment terhadap aspek WAC yang dilakukan pada gedung AHN Rektorat IPB menunjukkan bahwa perolehan poin nilai yang didapat adalah 5 poin dari nilai maksimal 20 poin sehingga telah memenuhi $25 \%$ dari rating yang telah di tetapkan greenship GBCI.

\section{Sumber dan Siklus Material (Material Resources and Cycle-MRC)}

Aspek MRC terdiri dari 3 rating prasyarat dan 5 rating biasa dengan total nilai maksimal adalah 12 poin. Hasil penilaian terhadap rating aspek ASD berdasarkan greenship adalah sebagai berikut:

a) Gedung AHN Rektorat IPB menggunakan refrigent tipe R22 denggan nilai ODP sebesar 0.05 .

b) Tolak ukur pada kategori Material Purchasing Practice adalah dokumen yang menjelaskan pembelanjaan material sesuai dengan kebijakan dalam prasyarat 2 yaitu pembelanjaan semua materil yang ramah lingkungan, paling sedikit 3 dari material yang diterapkan pada Daftar Material Ramah Lingkungan dalam 6 bulan terakhir. Berikut adalah daftar material ramah lingkungan tersebut :

a. $80 \%$ produksi regional berdasarkan total pembelanjaan material keseluruhan. 
b. $30 \%$ bersertifikat SNI/ ISO/ ecolabel berdasarkan total pembelanjaan material keseluruhan

c. 5\% material yang dapat didaur ulang (recycle) berdasarkan total pembelanjaan material keseluruhan.

d. $10 \%$ material bekas (reuse) berdasarkan total pembelanjaan material keseluruhan.

e. $2 \%$ material terbarukan (renewable) berdasarkan total pembelanjaan material keseluruhan.

f. $30 \%$ material modular atau pre fabrikasi berdasarkan total pembelanjaan material keseluruhan.

g. $100 \%$ kayu bersertifikat bedasarkan total pembelanjaan material kayu keseluruhan.

h. 2,5\% lampu yang tidak mengandung merkuri dari total unit pembelanjaan lampu.

i. Insulasi yang tidak mengandung styrene.

j. Plafond atau partisi yang tidak mengandung asbestos.

k. Produk kayu komposit dan agrifiber beremisi formaldehyde rendah.

1. Produk cat dan karpet yang beremisi VOC rendah.

Gedung AHN Rektorat IPB memenuhi poin a, j, l, g dan k. Untuk poin a, gedung AHN Rektorat IPB menggunakan material poduksi regional. Pada poin $\mathrm{j}$ gedung AHN Rektorat IPB menggunakan plafond gypsum non-asbestos dan partisi triplek. Pada poin 1 gedung AHN Rektorat IPB menggunakan cat vinilex dengan kadar VOC yang rendah. Sedangkan untuk poin $\mathrm{g}$ dan $\mathrm{k}$, gedung AHN Rektorat IPB kini tidak membeli lagi material kayu. Mengenai lampu, lampu yang digunakan masih lampu esensial dan lampu TL dan belum ada penggantian ke lampu yang lebih ramah lingkungan dan tidak mengandung merkuri.

c) Salah satu tolak ukur dalam kategori Waste Management Practice adalah adanya upaya penanganan sampah dari kegiatan renovasi kepihak ketiga minimal $10 \%$ dari total anggaran renovasi dalam 6 bulan terakhir. Untuk penanganan sampah gedung AHN Rektorat IPB, sekitar $80 \%$ dilakukan oleh pihak ketiga seperti pengumpulan, pengangkutan, dan pendaur ulangan material yang masih bisa digunakan. Untuk material yang sudah tidak digunakan lagi dibuang ke TPA oleh pihak kebersihan IPB.

d) Tolak ukur pada Management of Used Good adalah adanya Standar Prosedur Operasi dan laporan penyaluran barang bekas yang masih dapat dimanfaatkan kembali berupa furniture, elektronik, dan suku cadang melalui barang bekas dalam 6 bulan terakhir. Gedung AHN Rektorat IPB memiliki SOP mengenai Inventari dan Pelaporan Barang Milik IPB. Kegiatan inventarisasi meliputi pencatatan, pembukuan, opname fisik dan pelaporan yang wajib dilakukan dalam rangka tertib administrasi dalam mengelola barang, sekaligus memberikan pelayanan berupa data dan informasi secara benar.

Dalam peraturan tersebut pula mengatur tentang tata cara dan ketentuan penghapusan, pelelangan, dan tindak lanjut penghapusan barang inventaris milik IPB. Untuk penghapusan barang dilakukan berdasarkan pertimbangan teknis, ekonomis dan pertimbangan lainnya (karena hilang atau kelalaian bendaharawan barang atau kerugian). Barang-barang yang dihapuskan ataupun dilelang adalah barang bergerak seperti kendaraan ataupun barang tidak bergerak seperti furniture, elektronik, dan suku cadang. Dengan demikian kategori ini mendapatkan 1 poin nilai.

Hasil assessment terhadap aspek MRC yang dilakukan pada gedung AHN Rektorat IPB menunjukkan bahwa perolehan poin nilai yang didapat adalah 3 poin dari nilai maksimal 12 poin sehingga telah memenuhi $25 \%$ dari rating yang telah di tetapkan greenship GBCI. 


\section{Kesehatan dan Kenyamanan dalam Ruang (Indoor Health and Comfort-IHC)}

Aspek IHC terdiri dari 1 rating prasyarat dan 8 rating biasa dengan total nilai maksimal adalah 20 poin. Hasil penilaian terhadap rating aspek IHC berdasarkan greenship adalah sebagai berikut :

a) Gedung AHN Rektorat IPB telah membuat surat edaran dilarang merokok didalam ruangan, toilet, dan di lingkungan gedung AHN Rektorat IPB. Gedung AHN Rektorat IPB telah memasang kampanye berupa stiker dilarang merokok disetiap ruangan serta poster mengenai bahaya dari merokok serta surat himbauan untuk tidak merokok didalam gedung.

b) Introduction memuat tolak ukur mengenai kualitas udara ruangan yang menunjukkan adanya introduksi udara luar minimal sesuai dengan SNI-03-6572-2001 tentang Tata Cara Ventilasi dan Sistem Pengkondisian Udara pada Bangunan Gedung. Untuk hasil dari tolak ukur tersebut dilakukan pengukuran dan perhitungan mengenai laju udara ventilasi. Pengukuran dilakukan pada 14 ruangan yang mewakili ruangan-ruangan di tiap lantai mulai dari lantai 1 hingga lantai 6. Setelah dilakukan pengukuran kebanyakan kondisi didalam ruangan menggunakan $\mathrm{AC}$ dan cenderung tertutup, hanya ada 2 buah ruangan saja yang menggunakan ventilasi alami yaitu ruangan Biro Keuangan di lantai 3 , dan lobi lantai 6 . Berikut adalah hasil perhiungan dari 2 buah ruangan tersebut:

Tabel 4. Laju Udara Ventilasi

\begin{tabular}{|c|c|c|c|c|c|c|c|}
\hline \multirow{3}{*}{ Ruangan } & \multirow{3}{*}{$\begin{array}{c}\text { Kapasitas } \\
\text { Ruang }\end{array}$} & \multirow{3}{*}{$\begin{array}{c}\mathbf{V} \\
m / d t k \\
\end{array}$} & \multicolumn{2}{|c|}{ Laju Udara Ventilasi } & \multirow{3}{*}{$\begin{array}{c}\begin{array}{c}\text { Kebutuhan } \\
\text { udara* }\end{array} \\
\mathrm{m}^{3} / \mathrm{mnt} / \mathrm{org} \\
\end{array}$} & \multirow{3}{*}{$\begin{array}{c}\text { Volume } \\
\text { Ruangan } \\
\mathrm{m}^{3} \\
\end{array}$} & \multirow{3}{*}{ Keterangan } \\
\hline & & & $\mathbf{Q}$ & $\mathbf{Q}$ & & & \\
\hline & & & $m^{3} / d t k$ & $m^{3} / m n t$ & & & \\
\hline $\begin{array}{l}\text { Biro Keuangan } \\
\text { (Lt. 3) }\end{array}$ & 29 & 0.75 & 0.2918 & 0.0049 & \multirow[t]{2}{*}{0.15} & 566,61 & Tidak sesuai \\
\hline Lobby Lt.6 & 10 & 0.42 & 2.5807 & 0.0430 & & 360,56 & Tidak sesuai \\
\hline
\end{tabular}

*Sumber: SNI 03-6572-2001 tentang Tata Cara Ventilasi dan Sistem Pengkondisian Udara pada Bangunan Gedung, diolah.

Tabel 5. Laju Udara Ventilasi pada Kondisi Lain

\begin{tabular}{|c|c|c|c|c|c|c|c|}
\hline \multirow[b]{2}{*}{ Ruangan } & \multirow[b]{2}{*}{$\begin{array}{c}\text { Kapasitas } \\
\text { Ruang }\end{array}$} & \multirow{2}{*}{$\begin{array}{c}\mathbf{V} \\
(\mathrm{m} / \text { detik }) \\
\end{array}$} & \multicolumn{2}{|c|}{ Laju Udara Ventilasi } & \multirow{2}{*}{$\begin{array}{c}\text { Kebutuhan } \\
\text { udara } * * * \\
\left(m^{3} / \text { menit }\right) / \text { orang }\end{array}$} & \multirow{2}{*}{$\begin{array}{c}\text { Volume } \\
\text { Ruangan } \\
\left(\mathrm{m}^{3}\right)\end{array}$} & \multirow[b]{2}{*}{ Keterangan } \\
\hline & & & $\begin{array}{c}\mathbf{Q} \\
\left(m^{3} / \text { detik }\right)\end{array}$ & $\begin{array}{c}\mathbf{Q} \\
\left(\mathrm{m}^{3} / \text { menit }\right)\end{array}$ & & & \\
\hline $\begin{array}{l}\text { Biro } \\
\text { Keuangan } \\
\text { (Lt. 3) }\end{array}$ & 29 & $0.5833^{*}$ & 4.4114 & 0.0572 & & 566,61 & Tidak sesuai \\
\hline $\begin{array}{l}\text { Biro } \\
\text { Keuangan } \\
\text { (Lt. 3) }\end{array}$ & 29 & $0.75^{* *}$ & 3.4311 & 0.0735 & 0.15 & 566,61 & Tidak sesuai \\
\hline Lobby Lt.6 & 10 & $0.75 * *$ & 10.6857 & 0.1781 & & 360,56 & Sesuai \\
\hline Lobby Lt.6 & 10 & $0.5833^{*}$ & 8.31 & 0.1385 & & 360,56 & Tidak sesuai \\
\hline
\end{tabular}

*Kecepatan angin rata-rata Kabupaten Bogor. Sumber : Buku Putih Sanitasi Kabupaten Bogor, diolah.

**Kecepatan angin maksimal di area Gedung AHN Rektorat IPB

***Sumber: SNI 03-6572-2001 tentang Tata Cara Ventilasi dan Sistem Pengkondisian Udara pada Bangunan Gedung, diolah.

Pada Tabel 5 terlihat bahwa kondisi laju udara saat kecepatan angin normal dan maksimal di lobi lantai 6 adalah $0,1781 \mathrm{~m}^{3} /$ menit saat kondisi 15 jendela, 3 pintu dan 20 ventilasi terbuka.

c) Pengukuran kualitas udara yang dilakukan pada gedung AHN Rektorat IPB hanya dilakukan pada 3 parameter yaitu Nitrogen dioksida $\left(\mathrm{NO}_{2}\right)$, Sulfur dioksida $\left(\mathrm{SO}_{2}\right)$ dan Amonia $\left(\mathrm{NH}_{3}\right)$. Pada 6 ruangan yang mewakili tiap lantai nilai kualitas udaranya di 
bawah baku mutu, sehingga dinyatakan kualitas udara pada setiap ruangan di gedung AHN Rektorat IPB memiliki kualitas udara yang baik, tidak tercemar dan sesuai dengan peraturan yang berlaku.

Tabel 6. Hasil Pengukuran Kualitas Udara di Gedung AHN Rektorat IPB

\begin{tabular}{|c|c|c|c|c|c|}
\hline \multirow{2}{*}{ No } & \multirow{2}{*}{ Ruangan } & \multirow{2}{*}{ Parameter } & \multicolumn{2}{|c|}{ Konsentrasi $\left(\mathrm{mg} / \mathrm{m}^{3}\right)$} & \multirow{2}{*}{ Keterangan } \\
\hline & & & Terukur & Baku Mutu* & \\
\hline \multirow{4}{*}{1} & \multirow{4}{*}{ Lobby Basement (Lt. 1) } & $\mathrm{NO}_{2}$ & 0 & 5.6 & \\
\hline & & $\mathrm{SO}_{2}$ & 0.0022 & 5.2 & Sesuai \\
\hline & & $\mathrm{NH}_{3}$ & 0 & 17.0 & \\
\hline & & $\mathrm{NO}_{2}$ & 0 & 5.6 & \\
\hline \multirow[t]{3}{*}{2} & \multirow[t]{3}{*}{ Biro Umum (Lt. 1) } & $\mathrm{SO}_{2}$ & 0.0009 & 5.2 & Sesuai \\
\hline & & $\mathrm{NH}_{3}$ & 0 & 17.0 & \\
\hline & & $\mathrm{NO}_{2}$ & 0 & 5.6 & \\
\hline \multirow[t]{3}{*}{3} & \multirow[t]{3}{*}{ Lobby Utama (Lt. 2) } & $\mathrm{SO}_{2}$ & 0.0016 & 5.2 & Sesuai \\
\hline & & $\mathrm{NH}_{3}$ & 0 & 17.0 & \\
\hline & & $\mathrm{NO}_{2}$ & 0 & 5.6 & \\
\hline \multirow[t]{3}{*}{4} & \multirow[t]{2}{*}{ WR RK (Lt. 2) } & $\mathrm{SO}_{2}$ & 0.0014 & 5.2 & Sesuai \\
\hline & & $\mathrm{NH}_{3}$ & 0 & 17.0 & \\
\hline & \multirow{3}{*}{ Dit. Sarpras (Lt. 3) } & $\mathrm{NO}_{2}$ & 0 & 5.6 & \\
\hline \multirow[t]{3}{*}{5} & & $\mathrm{SO}_{2}$ & 0.0026 & 5.2 & Sesuai \\
\hline & & $\mathrm{NH}_{3}$ & 0 & 17.0 & \\
\hline & \multirow{3}{*}{ R. Sidang (Lt. 6) } & $\mathrm{NO}_{2}$ & 0 & 5.6 & \\
\hline \multirow[t]{2}{*}{6} & & $\mathrm{SO}_{2}$ & 0.0003 & 5.2 & Sesuai \\
\hline & & $\mathrm{NH}_{3}$ & 0 & 17.0 & \\
\hline
\end{tabular}

Sumber: Keputusan Menteri Kesehatan RI nomor 1405/Menkes/SK/XI/2002 tentang Persyaratan Kesehatan Lingkungan Kerja Perkantoran dan Industri, diolah.

d) Gedung AHN Rektorat IPB melakukan perawatan secara berkala setiap 3 bulan sekali berupa pembersihan AC.

e) Pengukuran tingkat kebisingan dilakukan secara acak sebanyak lima titik sampel dari minimal setiap ruang per dua lantai. Maka ruangan yang dilakukan pengukuran adalah ruangan Biro Umum lantai 1, Direktorat Sarana dan Prasarana Lantai 3, dan Lobby lantai 6. Berikut adalah hasil pengukuran tingkat kebisingan di gedung AHN Rektorat IPB:

Tabel 7. Hasil pengukuran tingkat kebisingan di gedung AHN Rektorat IPB

\begin{tabular}{|c|c|c|c|c|}
\hline \multirow{2}{*}{ Ruangan } & \multirow{2}{*}{$\begin{array}{c}\text { Tingkat } \\
\text { bunyi } \\
\text { terukur } \\
(d B A)\end{array}$} & \multicolumn{2}{|c|}{$\begin{array}{c}\text { Standar tingkat bunyi yang } \\
\text { dianjurkan }\end{array}$} & \multirow{2}{*}{ Keterangan } \\
\hline & & $\begin{array}{l}\text { Baik } \\
(d B A)\end{array}$ & $\begin{array}{c}\text { Maks. } \\
(d B A)\end{array}$ & \\
\hline Biro Umum (Lt. 1) & 48.7 & 40 & 45 & Tidak sesuai \\
\hline Dit. Sarpras (Lt.3) & 44.6 & 40 & 45 & Sesuai \\
\hline Lobby(Lt.6) & 50.6 & 45 & 50 & Tidak sesuai \\
\hline
\end{tabular}

Sumber: SNI 03-6386-2000 tentang Spesifikasi Tingkat Bunyi dan Waktu Dengung dalam Bangunan Gedung dan Perumahan, diolah.

f) Tolak ukur dalam kategori Building User Survey adalah mengadakan survey kenyamanan pengguna gedung antara lain meliputi suhu udara, tingkat pencahayaan ruang, kenyamanan suara, kebersihan gedung dan keberadaan hama pengganggu. Responden sebanyak 30\% dari total pengguna gedung tetap. Survei pada gedung AHN IPB Rektorat dilakukan dengan menggunakan pengisian kuisioner kepada 100 responden atau 31,8\% dari total 318 pengguna tetap gedung AHN Rektorat IPB. 
Hasilnya adalah $74,3 \%$ pengguna gedung merasa nyaman dan sisanya $25,7 \%$ pengguna gedung merasa tidak nyaman.

Hasil assessment terhadap aspek IHC yang dilakukan pada gedung AHN Rektorat IPB menunjukkan bahwa perolehan poin nilai yang didapat adalah 7 poin dari nilai maksimal 20 poin sehingga telah memenuhi $35 \%$ dari rating yang telah di tetapkan greenship GBCI.

\section{Manajemen Lingkungan Bangunan (Building Environment Management-BEM)}

Aspek BEM terdiri dari 1 rating prasyarat dan 5 rating biasa dengan total nilai maksimal adalah 13 poin. Hasil penilaian terhadap rating aspek BEM berdasarkan greenship adalah sebagai berikut:

Gedung AHN Rektorat IPB memiliki SOP sistem elektrikal yang berisi tentang perawatan rutin dan perbaikan/rehab instalasi listrik, SOP sistem plambing yang berisi tentang pedoman dan perawatan instalasi air, SOP sistem perawatan bangunan yang berisi pedoman perawatan bangunan bagi pengelola perbaikan/rehab, renovasi dan perluasan bangunan dan SOP sistem pengelolaan sampah. Kemudian gedung AHN Rektorat IPB pun memiliki struktur organisasi pihak pemelihara gedung yaitu divisi Biro Umum.

Inovasi yang dilakukan oleh gedung AHN Rektorat IPB adalah pada aspek ASD adalah adanya ruang terbuka hijau (RTH), pada aspek EEC yaitu energy monitoring system. Adanya aplikasi inovasi dengan melakukan pendekatan manajemen seperti mendorong perubahan perilaku. Gedung AHN Rektorat IPB telah melakukan pengurangan pemakaian kendaraan bermotor pribadi dengan menyediakan bus karyawan, fasilitas umum bus IPB di dalam kampus, adanya fasilitas mobil listrik, menyediakan akses pejalan kaki menuju bangunan lain tanpa melalui area publik dan adanya kerjasama dengan pihak ketiga untuk pengelolaan limbah B3 yaitu dengan PT. PPLI.Gedung AHN Rektorat IPB memiliki dokumen As Built Drawing dan dokumen yang menyatakan perubahan-perubahan fungsi bangunan. Pihak Biro Umum pun bertugas untuk menjaga penerapan sustainability/green building salah satunya yaitu program EMS merupakan salah satu program dibawah pengawasan pihak Biro Umum.

Hasil assessment terhadap aspek BEM yang dilakukan pada gedung AHN Rektorat IPB menunjukkan bahwa perolehan poin nilai yang didapat adalah 8 poin dari nilai maksimal 13 poin sehingga telah memenuhi $61,5 \%$ dari rating yang telah di tetapkan greenship GBCI.

Berikut adalah ringaksan tolak ukur yang terpenuhi hasil assessment terhadap kriteria green building yang dilakukan pada gedung AHN Rektorat IPB berdasarkan tolak ukur GREENSHIP untuk gedung terbangun versi 1.0 beserta rekomendasi bagi kriteria yang belum tercapai.

Tabel 8. Ringkasan Tolak Ukur GBCI untuk Gedung Terbangun Ver. 1.0 yang Terpenuhi oleh gedung AHN Rektorat IPB

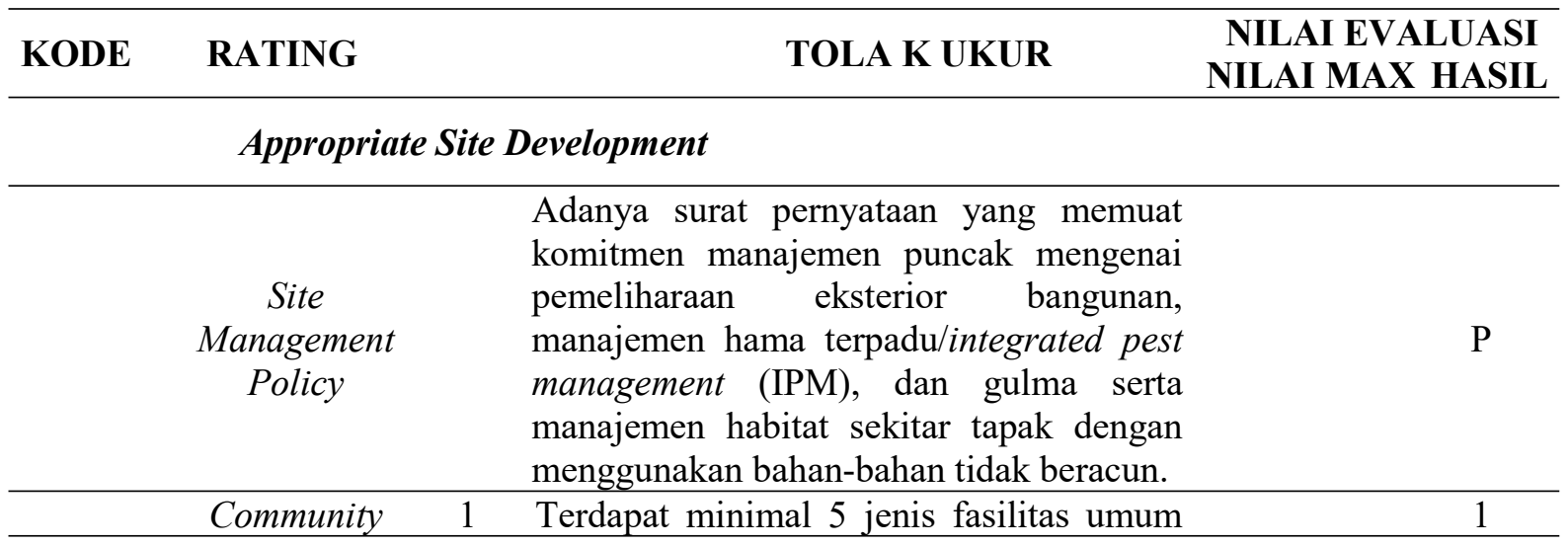




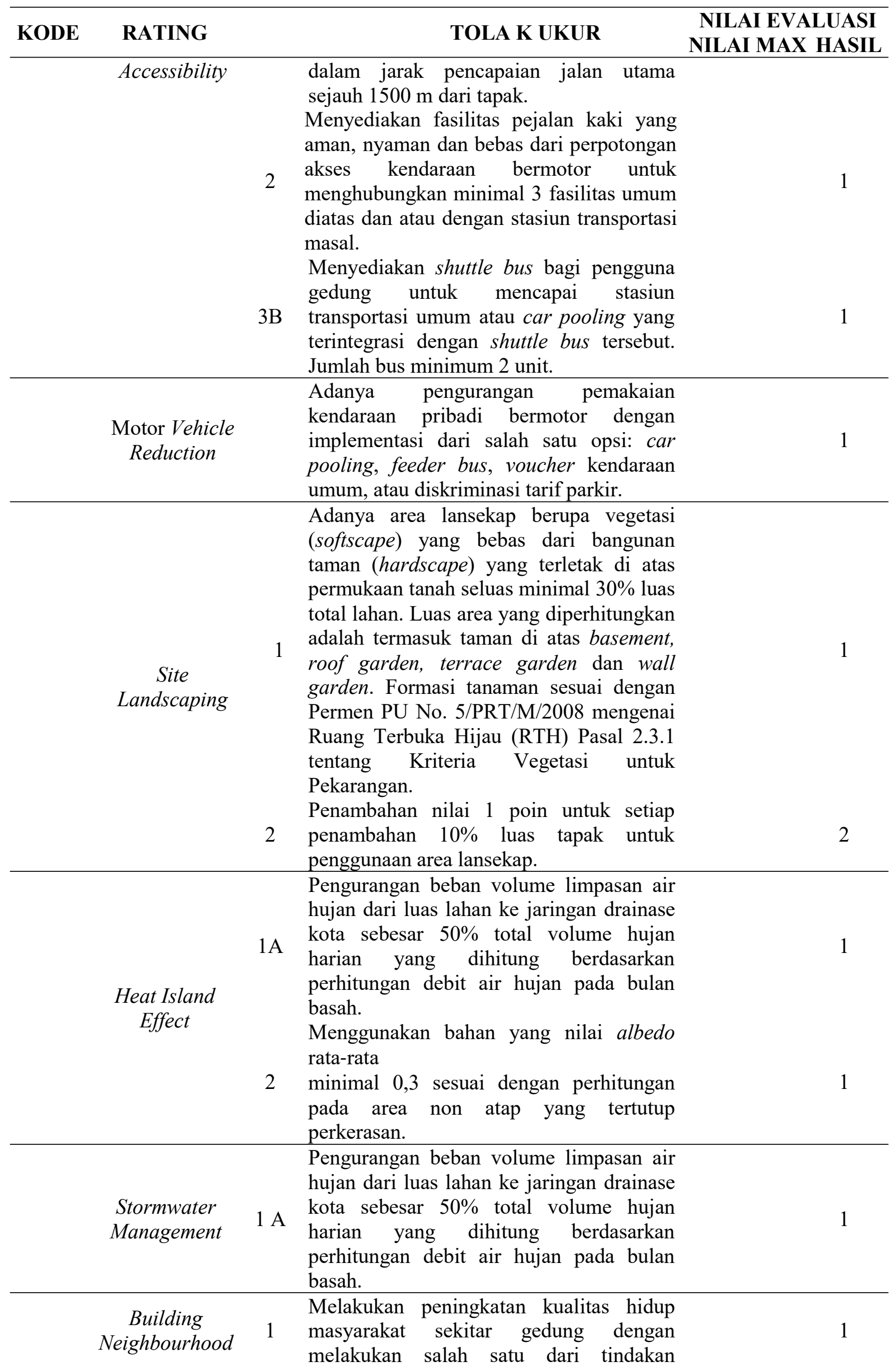




\begin{tabular}{|c|c|c|c|c|c|}
\hline \multirow[t]{3}{*}{ KODE } & \multirow[t]{2}{*}{ RATING } & \multicolumn{2}{|r|}{ TOLA K UKUR } & \multicolumn{2}{|c|}{$\begin{array}{l}\text { NILAI EVALUASI } \\
\text { NILAI MAX HASIL }\end{array}$} \\
\hline & & 3 & $\begin{array}{l}\text { berikut: perbaikan sanitasi, penyediaan } \\
\text { tempat beribadah, WC umum, kaki lima } \\
\text { dan pelatihan pengembangan masyarakat. } \\
\text { Mendedikasikan untuk kepentingan umum } \\
\text { baik } \\
\text { diwajibkan ataupun atas kesadaran sendiri } \\
\text { sebagian dari lahan terbukanya untuk } \\
\text { antara lain: utilitas umum (gardu listrik, } \\
\text { ventilasi dan ME stasiun bawah tanah, dan } \\
\text { sebagainya), pendukung jalur sirkulasi } \\
\text { umum (bus bay, lay by, dropoff) atau } \\
\text { untuk ruang terbuka hijau privat. }\end{array}$ & & 1 \\
\hline & & & Total $A S D$ & & 12 \\
\hline \multicolumn{6}{|c|}{ Energy Efficiency and Conservation } \\
\hline & $\begin{array}{c}\text { Policy and } \\
\text { Energy } \\
\text { Management } \\
\text { Plan }\end{array}$ & & $\begin{array}{l}\text { Adanya surat pernyataan yang memuat } \\
\text { komitmen dari manajemen puncak yang } \\
\text { mencakup: adanya audit energi, target } \\
\text { penghematan dan action plan berjangka } \\
\text { waktu tertentu oleh tim energi. }\end{array}$ & & $\mathrm{P}$ \\
\hline & $\begin{array}{l}\text { Optimized } \\
\text { Efficiency } \\
\text { Building } \\
\text { Energy } \\
\text { Performance }\end{array}$ & 1B & $\begin{array}{l}\text { Adanya kampanye dalam rangka } \\
\text { mendorong penghematan energi dengan } \\
\text { minimal pemasangan kampanye tertulis } \\
\text { secara permanen di setiap lantai, antara } \\
\text { lain berupa: stiker, poster, email. } \\
\text { Apabila IKE listrik gedung menunjukkan } \\
\text { nilai di bawah IKE listrik standar acuan } \\
\text { dalam } 6 \text { bulan terakhir, maka setiap } 3 \% \\
\text { penurunan akan mendapat } 1 \text { poin } \\
\text { tambahan sampai maksimal } 16 \text { poin. }\end{array}$ & $9-16$ & 16 \\
\hline & $\begin{array}{c}\text { Energy } \\
\text { Monitoring \& } \\
\text { Control }\end{array}$ & $1 \mathrm{~B}$ & $\begin{array}{l}\text { Adanya pencatatan rutin bulanan hasil } \\
\text { pantau dan koleksi data pada kWh meter. } \\
\text { Pencatatan dilakukan selama minimum } 6 \\
\text { bulan terakhir. } \\
\text { Menerapkan dukungan teknologi untuk } \\
\text { memonitoring dan mengontrol peralatan } \\
\text { gedung melalui teknologi EMS (Energy } \\
\text { Management System). }\end{array}$ & & 3 \\
\hline
\end{tabular}

Water Conservation

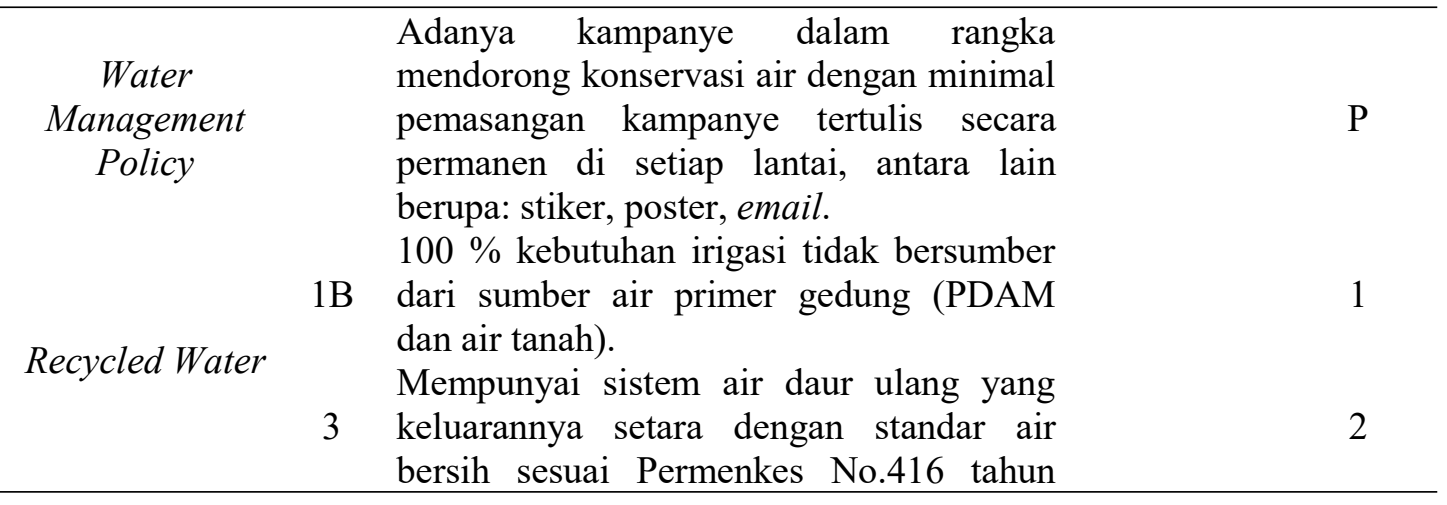




\begin{tabular}{|c|c|c|c|c|}
\hline \multirow[t]{4}{*}{ KODE } & RATING & & TOLA K UKUR & $\begin{array}{l}\text { NILAI EVALUASI } \\
\text { NILAI MAX HASIL }\end{array}$ \\
\hline & & & $\begin{array}{l}1990 \text { tentang Syarat-syarat dan } \\
\text { Pengawasan Kualitas Air untuk memenuhi } \\
\text { kebutuhan air bersih. }\end{array}$ & \\
\hline & $\begin{array}{l}\text { Deep Well } \\
\text { Reduction }\end{array}$ & $1 \mathrm{~A}$ & $\begin{array}{l}\text { Konsumsi air yang menggunakan deep } \\
\text { well maksimum } 20 \% \text { dari konsumsi air } \\
\text { secara keseluruhan. }\end{array}$ & 1 \\
\hline & & 1B & $\begin{array}{l}\text { Atau } \\
100 \% \text { kebutuhan irigasi tidak bersumber } \\
\text { dari sumber air primer gedung (PDAM } \\
\text { dan air tanah). }\end{array}$ & 1 \\
\hline & & & Total WAC & 5 \\
\hline
\end{tabular}

Material Resources and Cycle

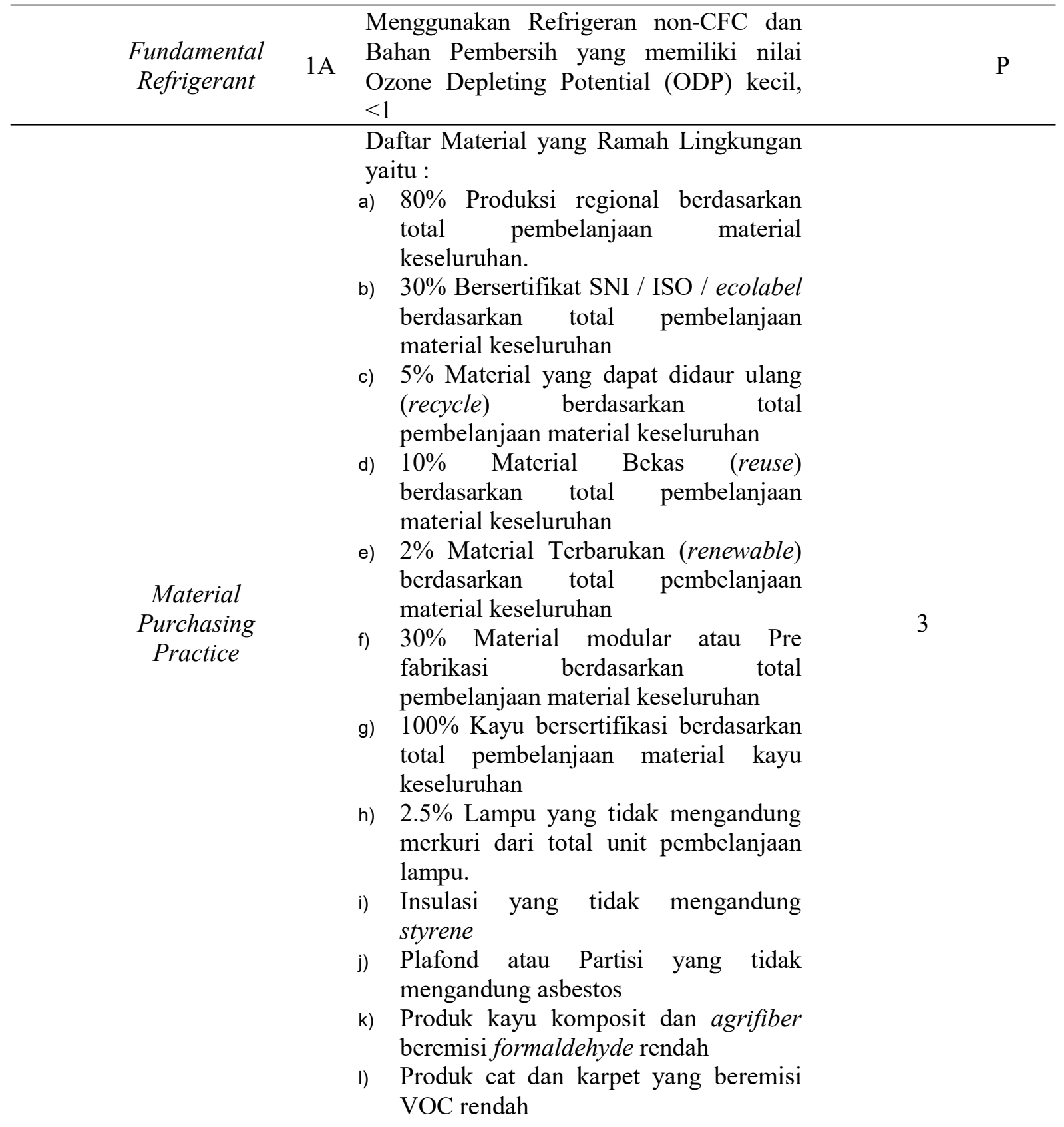




\begin{tabular}{|c|c|c|c|c|}
\hline KODE & RATING & & TOLA K UKUR & $\begin{array}{l}\text { NILAI EVALUASI } \\
\text { NILAI MAX HASIL }\end{array}$ \\
\hline & & $1 \mathrm{~A}$ & $\begin{array}{l}\text { Adanya dokumen yang menjelaskan } \\
\text { pembelanjaan material sesuai dengan } \\
\text { kebijakan dalam prasyarat 2, paling } \\
\text { sedikit } 3 \text { dari material yang ditetapkan } \\
\text { pada "Daftar Material Ramah } \\
\text { Lingkungan" dalam } 6 \text { bulan terakhir untuk } \\
\text { sertifikasi perdana. }\end{array}$ & 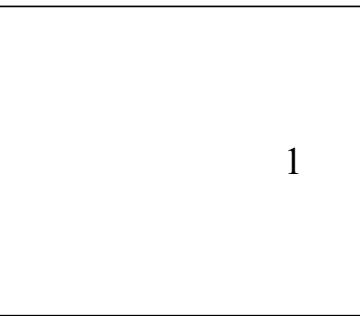 \\
\hline & $\begin{array}{l}\text { Waste } \\
\text { Management } \\
\text { Practice }\end{array}$ & 5 & $\begin{array}{l}\text { Adanya upaya penanganan sampah dari } \\
\text { kegiatan renovasi ke pihak ketiga minimal } \\
10 \% \text { dari total anggaran renovasi dalam } 6 \\
\text { bulan terakhir untuk sertifikasi perdana. }\end{array}$ & 1 \\
\hline & $\begin{array}{l}\text { Management of } \\
\text { Used Good }\end{array}$ & & $\begin{array}{l}\text { Adanya Standar Prosedur Operasi dan } \\
\text { laporan penyaluran barang bekas yang } \\
\text { masih dapat dimanfaatkan kembali berupa } \\
\text { furniture, elektronik, dan suku cadang } \\
\text { melalui donasi atau pasar barang bekas } \\
\text { dalam } 6 \text { bulan terakhir untuk sertifikasi } \\
\text { perdana. }\end{array}$ & 1 \\
\hline & & & Total MRC & 3 \\
\hline \multicolumn{5}{|c|}{ Indoor Health and Comfort } \\
\hline & $\begin{array}{l}\text { No Smoking } \\
\text { Campaign }\end{array}$ & & $\begin{array}{l}\text { Adanya surat pernyataan yang memuat } \\
\text { komitmen dari manajemen puncak untuk } \\
\text { mendorong minimalisasi aktifitas } \\
\text { merokok dalam gedung. } \\
\text { Adanya kampanye dilarang merokok yang } \\
\text { mencakup dampak negatif dari merokok } \\
\text { terhadap diri sendiri danlingkungan } \\
\text { dengan minimal pemasangan kampanye } \\
\text { tertulis secara permanen di setiap lantai, } \\
\text { antara lain berupa: stiker, poster, email. }\end{array}$ & $\mathrm{P}$ \\
\hline & $\begin{array}{l}\text { Outdoor Air } \\
\text { Introduction }\end{array}$ & & $\begin{array}{l}\text { Kualitas udara ruangan yang menunjukan } \\
\text { adanya introduksi udara luar minimal } \\
\text { sesuai dengan SNI 03-6572-2001 tentang } \\
\text { Tata Cara Ventilasi dan Sistem } \\
\text { Pengkondisian Udara pada Bangunan } \\
\text { Gedung }\end{array}$ & 2 \\
\hline & $\begin{array}{l}\text { Environmental } \\
\text { Tobacco Smoke } \\
\quad \text { Control }\end{array}$ & & $\begin{array}{l}\text { Dilarang merokok di seluruh area gedung } \\
\text { dan tidak menyediakan bangunan/area } \\
\text { khusus di dalam gedung untuk merokok. } \\
\text { Apabila menyediakan area khusus } \\
\text { merokok di luar gedung harus berjarak } \\
\text { minimal } 5 \mathrm{~m} \text { dari pintu masuk, tempat } \\
\text { masuknya udara segar dan bukaan jendela } \\
\text { dengan tindak lanjut prosedur } \\
\text { pemantauan, dokumentasi dan sistem } \\
\text { tanggap terhadap larangan merokok. }\end{array}$ & 2 \\
\hline & $\begin{array}{l}\text { Biological } \\
\text { Pollutant }\end{array}$ & 1 & $\begin{array}{l}\text { Pembersihan filter, coil pendingin dan alat } \\
\text { bantu VAC (Ventilation and Air } \\
\text { Conditioning) sesuai dengan jadwal } \\
\text { perawatan berkala untuk mencegah } \\
\text { terbentuknya lumut dan jamur sebagai }\end{array}$ & 1 \\
\hline
\end{tabular}




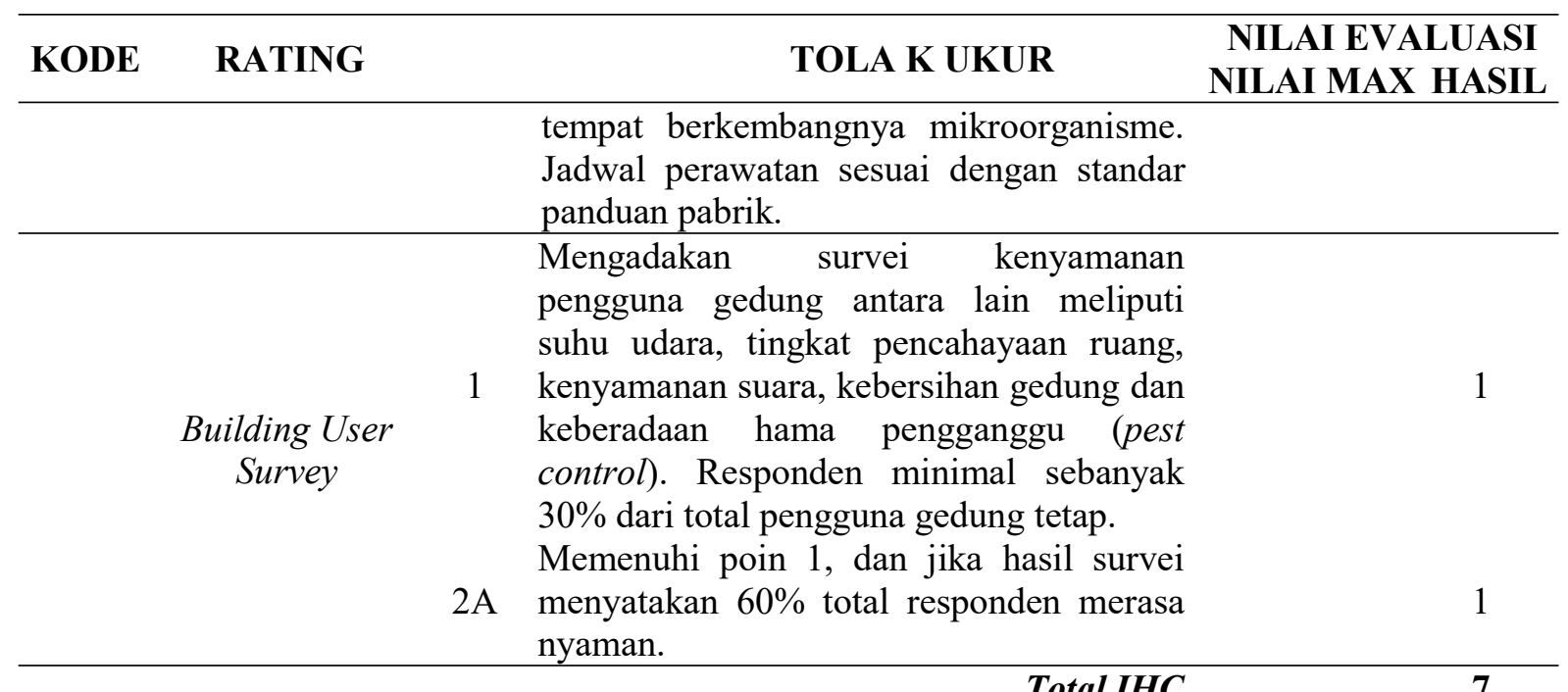

Total IHC

Building Environment Management

\begin{tabular}{|c|c|c|c|}
\hline $\begin{array}{c}\text { Operation \& } \\
\text { Maintenance } \\
\text { Policy }\end{array}$ & & $\begin{array}{l}\text { Adanya Rencana operation \& } \\
\text { maintenance yang mendukung sasaran } \\
\text { pencapaian rating-rating GREENSHIP } \\
\text { EB, dititikberatkan pada: sistem } \\
\text { mekanikal \& elektrikal, sistem plambing } \\
\text { dan kualitas air, pemeliharaan eksterior \& } \\
\text { interior, purchasing dan pengelolaan } \\
\text { sampah Mencakup: Struktur organisasi, } \\
\text { Standar Prosedur Operasi dan pelatihan, } \\
\text { program kerja, anggaran, laporan berkala } \\
\text { minimum tiap } 3 \text { bulan. }\end{array}$ & $\mathrm{P}$ \\
\hline Innovations & 2 & $\begin{array}{l}\text { Aplikasi inovasi dengan meningkatkan } \\
\text { kualitas bangunan secara kuantitatif, } \\
\text { contoh: ASD 4, EEC 1, WAC 3, dan IHC } \\
4 \text { sehingga terjadi peningkatan efisiensi } \\
\text { melebihi batas maksimum yang } \\
\text { ditentukan pada rating yang bersangkutan. } \\
\text { Aplikasi inovasi dengan melakukan } \\
\text { pendekatan manajemen seperti } \\
\text { mendorong perubahan perilaku, contoh } \\
\text { ASD } 2 \text { dan ASD } 8 \text { dan MRC 2, } 3 \text { dan 4, } \\
\text { sehingga terjadi peningkatan efisiensi } \\
\text { pada rating lain. }\end{array}$ & 3 \\
\hline $\begin{array}{c}\text { Design Intent \& } \\
\text { Owner's Project } \\
\text { Requirement }\end{array}$ & 1 & $\begin{array}{l}\text { Tersedianya dokumen Design Intent dan } \\
\text { Owner's Project Requirement berikut } \\
\text { perubahan-perubahannya yang terjadi } \\
\text { selama masa revitalisasi dan operasional. } \\
\text { Tersedianya dokumen As Built Drawing } \\
\text { (minimal single line drawing), spesifikasi } \\
\text { teknis dan manual untuk operasional dan } \\
\text { pemeliharaan peralatan (genset, } \\
\text { transportasi dalam gedung, AC dan } \\
\text { cooling tower) } \\
\text { perubahan-perubahannya yang terjadi } \\
\text { selama masa revitalisasi dan operasional. }\end{array}$ & 1 \\
\hline Green & 1 & Adanya satu struktur yang terintegrasi di & 1 \\
\hline
\end{tabular}




\begin{tabular}{clllc}
\hline \multirow{2}{*}{ KODE } & \multirow{2}{*}{ RATING } & \multicolumn{4}{c}{ TOLA K UKUR } & NILAI EVALUASI \\
NILAI MAX HASIL
\end{tabular}

Sumber: GBCI (2011) Greenship Rating Tools Version 1.0 untuk Gedung Terbangun, diolah.

Berdasarkan hasil beberapa analisis tersebut diatas, suatu rekomendasi bagi gedung AHN Rektorat IPB bisa dirumuskan sebagai berikut.

1. Pada System Energy Performance dapat dilakukan penggantian lampu TL $40 \mathrm{~W}$ dengan lampu hemat energi (LHE) $40 \mathrm{~W}$. Gedung AHN Rektorat IPB menggunakan lampu jenis Esensial $18 \mathrm{~W}$ sebanyak 396 buah, TL $40 \mathrm{~W}$ sebanyak 1.424 buah, TL $20 \mathrm{~W}$ sebanyak 20 buah, lampu LED 5 dan 7 W sebanyak 6 buah serta lampu sorot sebanyak 20 buah. Berikut adalah asumsi perbandingan jika dilakukan penggantian lampu TL 40 $\mathrm{W}$ dengan lampu hemat energi (LHE) $40 \mathrm{~W}$ :

Tabel 9. Perbandingan Lampu TL $40 \mathrm{~W}$ dan LHE $40 \mathrm{~W}$

\begin{tabular}{lll}
\hline \multirow{2}{*}{ Uraian } & \multicolumn{2}{c}{ Jenis Lampu } \\
\cline { 2 - 3 } & TL & LHE \\
\hline Daya listrik (W) & 40 & 40 \\
Pemakaian listrik (W) & 50 & 30 \\
Umur lampu (jam) & 8.000 & 8.000 \\
Jumlah lampu (bh) & 1 & 1 \\
Pemakaian listrik selama 8000 jam (kWh) & 400 & 240 \\
Harga kWh yang harus dibayar selama 8000 jam (Rp) & 354,000 & 212,400 \\
(Rp.885 per kWh) & &
\end{tabular}

Sumber: Prasetyo dan Islami (2014)

Berdasarkan Tabel 9 dapat dilihat bahwa dengan penggantian 1 buah lampu TL 40 ke lampu hemat energi terdapat penghematan pada pemakaian listrik sebesar $160 \mathrm{kWh}$ dan penghematan biaya pembayaran listrik sebesar Rp. 141.600 dalam satu hari. Jika gedung AHN rektorat memiliki jumlah lampu TL sebanyak 1.424 buah, maka dapat dilakukan penghematan pada pemakaian listrik sebesar $227.840 \mathrm{kWh}$ dalam sehari dan penghematan biaya sebesar Rp. 4.248.000 dalam sebulan.

1. Pada kategori On Site Renewable Energy dapat mencoba teknologi solar cell (panel surya) sebagai salah satu sumber untuk energi terbarukan.

2. Pada kategori Water Tap Efficiency dapat mencoba penggantian keran konvensional dengan keran yang mempunyai fitur auto stop (stop kran otomatis) sehingga ketika tidak digunakan kran tidak terus mengeluarkan air dan berhenti secara otomatis.

3. Pada kategori Non ODS Usage dapat mengganti jenis AC yang memiliki nilai ODP 0 seperti R410 A, R32 atau R290.

4. Pada kategori $\mathrm{CO} 2$ and $\mathrm{CO}$ Monitoring dapat mencoba untuk memasang sensor gas karbon dioksida $\left(\mathrm{CO}_{2}\right)$ untuk ruangan-ruangan dengan kepadatan tinggi.

5. Pengelolaa gedung AHN Rektorat IPB dapat mengikuti kegiatan pelatihan mengenai sertifikasi GBCI agar lebih memahami konsep green building menkepada pihak pengelola gedung AHN Rektorat IPB. 


\section{KESIMPULAN}

Berdasarkan hasil assessment terhadap enam aspek pada kriteria green building yang mengacu pada standar nasional Greenship GBCI dengan sistem rating untuk gedung terbangun ver. 1.0, gedung AHN Rektorat IPB berhasil mendapatkan total 55 poin nilai atau 47\% dari maksimal 117 poin nilai. Dengan rincian ketercapaian dalam tiap aspek adalah 12 poin nilai $(75 \%)$ pada aspek ASD, 20 poin nilai (56\%) pada aspek EEC, 5 poin nilai $(25 \%)$ pada aspek WAC, 3 poin nilai (23\%) pada aspek MRC, 7 poin nilai (35\%) pada aspek IHC dan 8 poin nilai $(61,5 \%)$ pada aspek BEM. Berdasarkan perolehan nilai tersebut maka sesuai dengan peringkat GREENSHIP GBCI, gedung AHN Rektorat IPB mendapatkan peringkat Perak.

\section{DAFTAR PUSTAKA}

Asdak, Chay. (2007).Hidrologi dan Pengelolaan Daerah Aliran Sungai. Gadjah Mada University Press. Yogyakarta.

Firsani, Trixy dan Utomo, Christiano. (2012).“Analisa Life Cycle Cost Pada Green Building Diamond Building Malaysia”. Jurnal Teknik ITS. ISSN: 2301-9271. Vol. 1. No. 1.

GBCI (2011). Greenship Rating Tools Version 1.0. untuk Gedung Terbangun. Green Building Council Indonesia. Jakarta.

GBCI (2013).Greenship Rating Tools Version 1.2 untuk Bangunan Baru. Green Building Council Indonesia. Jakarta.

Ichimura, T, Maeeda M, Fukumoto K, Kuroda K, Fukunaga R. (2014).“Approach to Energy Management for Companies”. FUJITSU Sci. Tech. Jurnal. Vol. 50. No. 2.

Kepmenkes 1405/2002. Keputusan Menteri Kesehatan RI) tentang Persyaratan Kesehatan Lingkungan Kerja Perkantoran dan Industri.

Komalasari, Rahayu I, Purwanto \& Suharyanto. (2013).“Kajian Green Building Berdasarkan Kriteria Tepat Guna Lahan (Appropriate Site Development) pada Gedung B Universitas Diponegoro Semarang". Prosiding Seminar Nasional Pengelolaan Sumberdaya Alam dan Lingkungan. 2013.. ISBN 978-602-17001-1-2

Morimura, T. (2000).Perencanaan dan Pemeliharaan Sistem Plambing.Pradya Paramita. Jakarta.

Permenkes 492/2010. Peraturan Menteri Kesehatan Nomor 492/MENKES/PER/IV/2010 tentang Persyaratan Kualitas Air Minum.

Prasetyo, Arif J dan Islami, Jamhir. (2014)."Manajemen Sisi Beban Untuk Penyusunan Peraturan Daerah Tentang Konservasi Energi di Kota Pontianak". Jurnal ELKHA Vol. 6. No.2.

Permenpu 5/2008. Peraturan Menteri Pekerjaan Umum No. 5/PRT/M/2008 mengenai Ruang Terbuka Hijau (RTH).

Rushayati, Siti B, Alikodra, Hadi S \& Dahlan, Endes N. (2010).Pengembangan Ruang Terbuka Hijau Berdasarkan Distribusi Suhu Permukaan di Kabupaten Bandung. Insitut Pertanian Bogor. Bogor.

Satwiko, Prasasto. (2009). Fisika Bangunan. ANDI.Yogyakarta.

SNI 03-6197-2000. Standar Nasional Indonesia 03-6197-2000 tentang Konservasi Energi pada Sistem Pencahayaan.

SNI 03-6386-2000. Standar Nasional Indonesia 03-6386-2000 tentang Spesifikasi Tingkat Bunyi dan Waktu Dengung dalam Bangunan Gedung dan Perumahan.

SNI 03-6572-2001. Standar Nasional Indonesia 03-6572-2001 tentang Tata Cara Ventilasi dan Sistem Pengkondisian Udara pada Bangunan Gedung.

SNI 03-7065-2005. Standar Nasional Indonesia 03-7065-2005 tentang Tata Cara Pelaksanaan Sistem Plambing. 
Soemitro, R.A.A. \& Suprayitno, H. (2018). "Pemikiran Awal tentang Konsep Dasar Manajemen Aset Fasilitas". Jurnal Manajemen Aset Infrastruktur \& Fasilitas, Vol. 2, Suplemen 1, Juni 2018, Hal. : 1-14.

Suprayitno, H. \& Soemitro, R.A.A. (2018). "Preliminary Reflexion on Basic Principle of Infrastructure Asset Management". Jurnal Manajemen Aset Infrastruktur \& Fasilitas, Vol. 1, No. 1, Maret 2018, Hal. : 1-10. 
(e)ISSN 2615-1847 $\quad$ (p)ISSN 2615-1839

Jurnal Manajemen Aset Infrastruktur \& Fasilitas - Vol. 3, No. 2, September 2019 